\title{
Support of pre-professional development of high school students focused on teaching professions
}

\section{Apoio ao desenvolvimento pré-profissional de alunos do ensino médio com foco em profissões docentes}

\section{Apoyo al desarrollo pre profesional de estudiantes de secundaria enfocado en profesiones docentes}

\author{
Anna Pavlovna Chernyavskaya ${ }^{1}$ (D) Luidmila Vasilievna Bayborodova $^{1}$ iD \\ ${ }^{1}$ Yaroslavl State Pedagogical University named after K.D. Ushinsky, Yaroslavl, Russia. \\ Corresponding author: \\ Anna Pavlovna Chernyavskaya \\ Email: achernyavskaya@yandex.ru \\ How to cite: Chernyavskaya, A. P., \& Bayborodova, L. V. (2021). Support of pre-professional development of high \\ school students focused on teaching professions. Revista Tempos e Espaços em Educação, 14(33), e16912. \\ http://dx.doi.org/10.20952/revtee.v14i33.16912
}

\begin{abstract}
All teaching professions are at high importance for children, their parents, and society at whole. Teachers, their skills and personality, play a big role in the development and education of young generations. Children usually make decisions to be a teacher at young ages, and support in this decision, pre-professional development helps them to be a good teacher in the future. There are different programs and method which help schoolchildren in this process. In this article few topics had been discussed: results of all-Russian monitoring of pre-professional education of high-school students, focused on teaching professions; main factors of vocational choice; forms and methods of pre-professional support. The main questions of our study were as follows: under what conditions within the framework of the system of General and High Education it is possible to help the highschool students determine the near and far prospects of his personal and professional development before entering Teaching University or College, what should be the content of this work? Few programs, existing in various regions of the Russian Federation are discussed. The conditions for the pedagogical support for the formation of professional readiness for further teaching were identified: the creation of a specially organized educational and socializing environment, such as pre-university programs, or school-based programs (local or Regional); different kinds of Olympiads and competitions; taking into consideration the characteristics of students.

Keywords: Pre-professional development. High-school students. Pedagogical support. Teaching professions.
\end{abstract}




\section{RESUMO}

Todas as profissões de ensino são de grande importância para as crianças, seus pais e a sociedade como um todo. Os professores, suas habilidades e personalidade, desempenham um grande papel no desenvolvimento e na educação das jovens gerações. As crianças geralmente tomam decisões sobre ser professores em idades jovens e, ao apoiar essa decisão, o desenvolvimento préprofissional os ajuda a serem bons professores no futuro. Existem diferentes programas e métodos que auxiliam os alunos neste processo. Neste artigo, alguns tópicos foram discutidos: resultados de monitoramento totalmente russo da educação pré-profissional de alunos do ensino médio, com foco nas profissões docentes; principais fatores de escolha profissional; formas e métodos de apoio pré-profissional. As principais questões do nosso estudo foram as seguintes: em que condições no âmbito do sistema de Educação Geral e Superior é possível ajudar os alunos do ensino médio a determinar as perspectivas próximas e distantes de seu desenvolvimento pessoal e profissional antes de ingressar na Universidade de Ensino ou faculdade, qual deve ser o conteúdo deste trabalho? Alguns programas existentes em várias regiões da Federação Russa são discutidos. Identificaram-se as condições de apoio pedagógico para a formação da preparação profissional para a continuação da docência: a criação de um ambiente educativo e socializante especialmente organizado, como os programas pré-universitários, ou os programas escolares (locais ou regionais); diferentes tipos de olimpíadas e competições; levando em consideração as características dos alunos.

Palavras-chave: Desenvolvimento pré-profissional. Alunos do ensino médio. Apoio pedagógico. Profissões de ensino.

\section{RESUMEN}

Todas las profesiones de la enseñanza son de gran importancia para los niños, sus padres y la sociedad en general. Los profesores, sus habilidades y personalidad, juegan un papel importante en el desarrollo y la educación de las generaciones jóvenes. Los niños suelen tomar decisiones para ser maestros a edades tempranas, y el apoyo en esta decisión, el desarrollo preprofesional les ayuda a ser buenos maestros en el futuro. Existen diferentes programas y métodos que ayudan a los escolares en este proceso. En este artículo se han discutido pocos temas: resultados del seguimiento de la educación preprofesional de los estudiantes de secundaria en toda Rusia, centrado en las profesiones docentes; principales factores de elección vocacional; formas y métodos de apoyo preprofesional. Las principales cuestiones de nuestro estudio fueron las siguientes: en qué condiciones en el marco del sistema de Educación General y Superior es posible ayudar a los estudiantes de secundaria a determinar las perspectivas cercanas y lejanas de su desarrollo personal y profesional antes de ingresar a la Docencia Universitaria. o Colegio, ¿cuál debería ser el contenido de este trabajo? Se examinan pocos programas existentes en varias regiones de la Federación de Rusia. Se identificaron las condiciones para el apoyo pedagógico para la formación de la preparación profesional para la enseñanza posterior: la creación de un entorno educativo y socializador especialmente organizado, como programas preuniversitarios o programas escolares (locales o regionales); diferentes tipos de olimpiadas y competiciones; teniendo en cuenta las características de los estudiantes.

Palabras clave: Desarrollo preprofesional. Estudiantes de secundaria. Apoyo pedagógico. Profesiones docentes.

\section{INTRODUCTION}

World surveys show that teachers are second only to the military and doctors in the ranking of professions on which the welfare of society depends. We would raise this point even higher, because the present and future of every child depends on teachers. In 2013, the rating of the teacher's profession in terms of trust was 3.72 points out of five possible (only scientists have a 
higher indicator -3.86 points). The researchers note that a teacher is just as difficult a profession as an air traffic controller, pilot or firefighter. Their stress level is approximately at the same level (Davydova, 2018; Smak \& Walczak, 2017).

According to the Protocol of the meeting of the Board of the Ministry of Education of the Russian Federation dated October 20, 2020, the key guideline for the development of modern education is to ensure the competitiveness of domestic education, increase the effectiveness of educating the younger generation, and quality training of teachers. A necessary stage and a condition for successful continuous training of pedagogical personnel is to build a unified system of teacher training, starting with pre-professional training at school, creating favorable conditions for the orientation of graduates of the general education system to pedagogical and psychologicalpedagogical professions.

The period of entering into profession has a profound impact upon the proficiency development of a specialist. For a teacher, it is the time of intensive competence checkup as well as self-presentation, adaptation, and what's more important, self-determination. Having engaged in teaching, gradually plunging into the profession, getting to know it, he is to decide whether his occupation choice was correct and if he is willing to get involved into education for long. Some beginners in teaching get disappointed with the profession, or rather their capability to deal with it, and have to resign.

The education of a future teacher is an important and very noble task. It begins long before a school graduate enters a pedagogical university - by parents, school teachers. It is possible to make this process more organized and purposeful in the process of pre-professional training. Training in pedagogical classes or in the process of studying elective courses of psychological and pedagogical orientation initially gives future teachers an idea of the social role of education, guidelines and content that reflect the new realities and values of modern society (Ministry of Education of the Russian Federation, 2018).

However, in recent decades, the problem of reducing the prestige of the teaching profession in society and the need to attract teaching staff has been discussed in the scientific pedagogical and political literature. The quality of a teacher's work, in the context of students' academic performance and the quality of knowledge (Hattie, 2003; Lyng \& Blichfeldt, 2003), is considered as a long-term impact on the economic competitiveness of society in a globalized market (Heinz, 2015). Scientists come to the conclusion that quality education cannot be achieved without teachers who are motivated, enthusiastic and convinced of the value of their students' education and the teaching profession (Manning \& Patterson, 2005; Yüce et al., 2013; Watt et al., 2012). Scientific research has established that the motives, values and orientations that students have before entering the pedagogical specialties have a significant impact on their work as teachers (Aksu et al, 2010; Goodson, 2003; Richardson \& Watt, 2006; Struven et al., 2013). The shortage of teachers is defined by UNESCO as a global problem affecting countries around the world (UNESCO Institute of Statistics, 2013). The involvement of motivated, purposeful and dedicated teachers of young people is determined by the problem of global politics (Heinz, 2015).

A significant number of applicants, poorly representing the activity of a teacher, become casual students in this field of professional education and, even after finishing their education and coming to school, they leave in the first year of work (Chernyavskaya et al., 2021; Kyriacou \& Coulthard, 2000). The experience of a number of countries, for example, Austria and France, shows that the stability of the work of young teachers is largely due to the policy of early selection and individual support of students and novice teachers at school, which creates optimal conditions for their professional development and individual support (Brok et al., 2017; Choi \& Tang, 2009; Danilova, 2018; European Commission/EACEA/Eurydice, 2015).

The international research community finds interrelations between awareness of the choice of a pedagogical profession and the quality of a teacher's work. Studies devoted to the study of 
teachers 'professional identity reveal the influence of biographical factors, such as teachers' own school experience, their motives for entering teacher education programs on the formation of teachers ' professional identity, their success and effectiveness of their teaching activities (Flores \& Day, 2012; Stronge et al., 2008, 2011).

In this regard, an important stage of training is career guidance and pre-professional pedagogical education, the identification and development of schoolchildren who have a tendency to pedagogical activity (Brown, 2002; Chernyavskaya, 2017; Rikard, 1999).

There are number of ways to support teachers in their work, professional choice, stability, and development. One of those ways: start to support future teachers very early - in their precareer development, when they just make decision whether to be teacher, or not.

\section{RESEARCH METHODS}

In the autumn of 2020, the questionnaire for monitoring the state of pre-professional pedagogical training of high school students had been provided with the help of Ministry of Education of Russian Federation. The questionnaire was conducted in 87 regions of the Russian Federation. Among others, this monitoring had such questions as:

- The presence of a regional program (project) or a section in the educational development program of the subject for the organization of pre-professional pedagogical training of schoolchildren.

- Implemented formats of pre-professional pedagogical training of schoolchildren

- Online pedagogical (psychological and pedagogical) class.

- Implementation of additional education programs for children aimed at pre-professional pedagogical training.

- Tools for evaluating the effectiveness of pre-professional pedagogical training of schoolchildren (list if available).

- General education organizations that have the most successful experience in the activities of specialized pedagogical classes.

- Organizations of additional education of children, organizations of secondary professional (pedagogical) education, other organizations that have the most successful experience in implementing additional education programs for children aimed at pre-professional pedagogical training.

- Experience in holding regional and municipal Olympiads and other competitions aimed at identifying pedagogically gifted schoolchildren.

- Names of regional and municipal Olympiads and other competitions aimed at identifying pedagogically gifted schoolchildren.

- The number of electronic resources aimed at pre-professional pedagogical training.

- The number of methodological associations of teachers in the subject who oversee the activities of pedagogical classes and other associations of schoolchildren.

The monitoring data were studied and summarized. In addition, the materials of websites, the experience of general education organizations were studied on the basis of the documents and publications provided, conversations were held with teachers involved in pre-professional pedagogical training of schoolchildren.

\section{RESULTS}

The results of the analysis showed that in the whole country, only $4 \%$ of educational organizations implement programs of pre-professional pedagogical training. The analysis carried out by Federal Districts showed that the most favorable situation (in terms of the ratio of educational organizations in general and public organizations implementing pre-professional 
pedagogical training programs) for the organization of pre-professional pedagogical training in the Far Eastern and Southern Federal Districts, although in \%\% ratio these figures are also very small.

Table 1. Educational organizations, fulfilled programs of pre-professional teachers' education.

\begin{tabular}{|c|c|c|c|}
\hline Federal District & $\begin{array}{l}\text { Total amount of } \\
\text { educational } \\
\text { organizations }\end{array}$ & $\begin{array}{l}\text { Amount of } \\
\text { educational } \\
\text { organizations, } \\
\text { fulfilled programs of } \\
\text { pre-professional } \\
\text { teachers' education }\end{array}$ & $\begin{array}{l}\text { The number of } \\
\text { educational organizations } \\
\text { implementing other } \\
\text { forms of pre-professional } \\
\text { teachers training }\end{array}$ \\
\hline Central Federal District & 6326 & 57 & 157 \\
\hline Southern Federal District & 6547 & 273 & 44 \\
\hline North-Western Federal District & 3959 & 6 & 8 \\
\hline Far Eastern Federal District & 1071 & 40 & 64 \\
\hline Siberian Federal District & 9521 & 79 & 216 \\
\hline Ural Federal District & 1775 & 5 & 159 \\
\hline Volga Federal District & 10142 & 91 & 120 \\
\hline Northern Caucasus & 4832 & 36 & 61 \\
\hline Crimean Federal District & 564 & 4 & 0 \\
\hline
\end{tabular}

In general, it can be noted that it is very difficult to give sufficiently complete and accurate information about the presence of psychological and pedagogical classes, associations of sociopedagogical orientation and their activities due to the fact that most of the digital data is not always confirmed by regulatory documents, curricula. In addition, during a random check, we found that a number of regions did not provide information about the presence of pedagogical classes (groups, associations of students of psychological and pedagogical or socio-pedagogical orientation), since today they are created on the basis of pedagogical and other universities or colleges, which the regional education departments are not always informed about.

A pedagogical (psychological and pedagogical) class based on one general education organization is the most common form. He works in $52 \%$ of educational organizations that implement pre-professional pedagogical training. In $40 \%$ of cases, the pedagogical class is organized using the resources of both the main and additional educational programs. The organization of a pedagogical class only within the framework of the main or only within the framework of an additional educational program occurs with the same frequency - $30 \% \%$ of educational organizations.

The experience of organizing a teaching class on the basis of several educational institutions is very promising, since it opens up great opportunities in terms of resource provision and a variety of training programs. In this case, the forms of interaction organization can be different - within the framework of network interaction, in a network form, on the basis of a school-resource center, etc. The center of the organization of a distributed pedagogical class, as will be shown below, can be not only a school, but also a university, a pedagogical college and other organizations.

In the whole country, distributed pedagogical classes work on the basis of $38 \%$ of educational organizations that implement programs of pre-professional pedagogical training. At the same time, it is most often organized within the framework of an additional educational program-50\%, or a combination of basic and additional educational programs-33\% of educational organizations.

Online pedagogical (psychological and pedagogical) class is implemented in $14 \%$ of educational organizations engaged in pre-professional pedagogical training. The biggest experience in organizing online pedagogical (psychological and pedagogical) classes has been accumulated in the Siberian Federal District (34\%) and the Volga Federal District (25\%). Pedagogical classes in the 
Central and North Caucasus Federal Districts are not implemented in an online format (according to the data provided by the regions).

\section{DISCUSSION}

The system of identifying pedagogically focused schoolchildren is based on two main components: the system of educational practices of specialized pedagogical (psychological and pedagogical) classes and the resources of competitive events of psychological and pedagogical orientation, presented in different organizational forms and implemented at different levels.

Currently, in order to provide scientific and methodological support for the system of identifying pedagogically gifted schoolchildren, the Ministry of Education of the Russian Federation is developing a "Concept of specialized psychological and pedagogical classes". Methodological support of the system will be provided with a set of educational and methodological materials for the implementation of educational activities in specialized psychological and pedagogical classes.

The analysis of the experience of organizing activities to identify pedagogically gifted schoolchildren in the regions of the Russian Federation, conducted on the basis of materials from 87 regions, showed that pre-professional pedagogical training programs are implemented in various forms. In general, the share of educational organizations implementing teacher training programs in relation to the total number of educational organizations is only $4 \%$.

The system for identifying pedagogically focused high-school students may include the following blocks: Diagnostics: personal characteristics necessary for successful pedagogical activity, interests, knowledge and skills; Organization of pre-professional pedagogical training of students, which should be one of the stages of continuous pedagogical education; Volunteer and sociopedagogical activities that can be carried out outside of training in pedagogical classes and are recorded in volunteer books or other documents; Competitions and Olympiads of different levels (from the level of an educational organization to the federal one) - pedagogical, psychological and pedagogical, interdisciplinary, etc.

The experience of integrating the system of identifying pedagogically focused high-school students into the educational component of the activities of general education organizations is interesting on the basis of including the variable module "Psychological and pedagogical class" in the working programs of school education or using this module as part (direction) of such invariant modules of the program as "Career guidance", "Self-government", "Key school-wide affairs".

An important aspect of the activity to identify pedagogically focused high-school students is the assessment of the educational and educational results of students of psychological and pedagogical classes and students enrolled in additional general education programs of a profile orientation.

Based on the results of monitoring, we came to the conclusion about main forms and aspects of pre-professional development of high-school students focused on teaching professions:

1. Inclusion of pre-professional training in the system of continuing pedagogical education.

In some regions of the Russian Federation, such a system of work is already being created, in which, starting from the pre-professional level, conditions are created for continuous and systematic training of pedagogical personnel, which includes pedagogical and psychologicalpedagogical classes, including through the use of: new forms of career guidance, modern digital technologies, participation in professional associations and competitions, participation in exchange programs of experience and best practices.

The example of Ulyanovsk State University, where there is a college for students of grades 10-11, has already been given above.

As an example, we can highlight the experience of a systematic and integrated approach to training personnel for the education system in the Republic of North Ossetia-Alania, where the 
project "Training personnel for the education system" is being implemented since 2018, which has a section of pre-professional training.

2. Organization of psychological and pedagogical training in the region on the basis of or with the involvement of pedagogical universities and colleges using online platforms and resources.

This direction allows students from different educational organizations, regardless of their place of residence, to actively participate in educational programs and events; provides an opportunity to attract a larger circle of specialists in the social and pedagogical sphere for interaction and transfer of experience, the integration of many professionals of the pedagogical community; provides wide access to open digital resources.

The successful implementation of this idea, for example, is carried out in the Volgograd State Socio-Pedagogical University. Such interaction helps not just to focus on the profession, but to purposefully develop the value-semantic sphere necessary for students to work in teaching professions.

As an example, we can cite the Ural State Pedagogical University, which has been operating as part of the pedagogical cluster of the Sverdlovsk Region since 2020 on the basis of MAOU Secondary School No. 166. Ekaterinburg. Classes are held in the following disciplines:

- "Introduction to the professional activity of a teacher" (78 hours of the first year of study and 44 hours of the second); - "I am a leader: strategies for success" (52 hours for two years of training); - "Fundamentals of intercultural communication" (70-80 hours for grades 10-11; the volume may vary depending on the conditions of the organization).

3. Practice-oriented training aimed at developing the skills and abilities necessary for activities in the social and pedagogical sphere, which involves the acquisition of new knowledge and the formation of practical experience based on the inclusion of students in specific situations and their solution of real applied problems. An example is the secondary school No. 28 named after A. A. Surkov in Rybinsk, Yaroslavl region, on the basis of which there is a pedagogical class for students of grades $10-11$, in which students from other schools of the city have been studying for several years. Students of the pedagogical class of the basic level of education attend compulsory elective subjects and extracurricular classes of a psychological and pedagogical orientation and the pedagogical practice "First professional tests" on the basis of a kindergarten, are involved in the organization of the educational process on the basis of the "Regulations on the assistant class teacher", participate in the organization of the educational process in primary school, summer school health camp.

4. The use of modern forms and methods of teaching in the process of psychological and pedagogical training.

In some regions, there are interesting methods and organizational forms that promote orientation to teaching professions.

An example is the "Pedagogical Pre-University" and a network pedagogical class from the Tambov State University named after G. R. Derzhavin. The "Pedagogical Pre-University" model is based on the principle of immersion, when school students become equal participants in the student life of the Pedagogical Institute of TSU named after G. R. Derzhavin. The network pedagogical class creates an innovative educational environment for schoolchildren from remote areas of the Tambov region.

According to the results of training under the additional general development program "Cambridge Junior", for the first time in Russia, schoolchildren of Rostov, Yaroslavl region were invited to take part in a demonstration exam according to WorldSkills Russia standards for the competence "Preschool education". 6 schoolchildren took part in the exam procedure. The examinees performed the tasks of two modules. 


\section{Development of individual curricula with offset of educational results.}

In 2020, 11 educational organizations of general, additional, secondary and higher professional education of the Yaroslavl region took part in the approbation of the project developed by the Higher School of Economics in this direction. All students in the process of implementing this model were transferred to training according to an individual curriculum. The model of crediting the results of the implementation of three additional general educational general development programs of socio-pedagogical orientation was implemented as part of the development of the main general education programs of schools - extracurricular activities, elective courses, projectbased training of schoolchildren.

\section{competitions.}

6. Attracting students of pedagogical classes to participate in professional skill

it provides for the organization of a system of pedagogical Olympiads, competitions, festivals, educational projects of professional orientation at various levels, which allows attracting everyone to an objective assessment and development of professionally important qualities, promotes the promotion of the teaching profession, the development of a system of support for pedagogically gifted students, stimulating professional self-determination of high school students.

Today, the regions of Russia have accumulated a rich and diverse experience in solving this problem through competitive events, including Olympiads, at the All-Russian and regional levels.

For example, the contest "Student of the year", with 20 years of history, which originated in Ulyanovsk region and became one of the most popular and popular among high school students throughout Russia, in 2009 reached the level of the Volga Federal district and in 2019 the competition was included in the national list of Olympiads and other intellectual and (or) creative competitions, enabling the identification of socially active young people, including those with important competences for professional pedagogical activity.

In many regions, a pedagogical (psychological and pedagogical) Olympiad of high-school students is held. For example, in the late 80 s-early 90 s of the twentieth century, this tradition originated in the Yaroslavl region. Olympiads have become a kind of brand in the pedagogical life of the region and have served as an important means of identifying pedagogically gifted children. Since 2020, this Olympiad has acquired the status of an All-Russian Olympiad, is included in the List of Olympiads and other intellectual and (or) creative competitions, and is one of the key events of the National Project "Education" and its federal projects "The Success of every Child" and "Teacher of the Future". In 2021, at the final stage, more than two hundred schoolchildren from 16 regions took part in it, where regional Olympiads were previously held with coverage from 100 to 200 people in each region.

A new modern form of evaluation of results is a demonstration exam according to the WorldSkills Russia standards for pedagogical competencies, which is currently used as a variant of the final certification of the development of additional general development programs by students. The experience of conducting such an exam on pedagogical competencies is available in the Yaroslavl, Orenburg, Omsk regions, the Republic of Mordovia, the Republic of Altai and other regions.

7. Development and organization of scientific and methodological support for the activities of pedagogical and psychological-pedagogical classes.

8. Development and implementation of teacher training programs and specialists involved in the activities of psychological and pedagogical classes; wide involvement of teachers of pedagogical universities and colleges, senior students, organization of pedagogical practice of students on the basis of pedagogical classes; creation of public organizations, associations of teachers of the teaching staff at the federal and regional levels.

A promising line is the development of the concept of a pre-professional exam for applicants of pedagogical universities, which will allow for continuity in the assessment of educational results 
at the level of general, additional and higher professional pedagogical education. For example, in the model of continuing education developed by Tomsk State Pedagogical University (TSPU), the platform "Open Pedagogical Class" is an organizational form of propaedeutics (grades 8-9) and specialized (grades 10-11) stages. The resources of the platform are used in the organization of pedagogical training of schoolchildren in all districts of the region. Districts create their own fulltime and distance classes, in which teachers of the district's schools teach. TSPU offers the content of training, support and professional development of teachers. Part of the training is the Pedagogical Olympiad, which is held in several stages. The first stages are at the level of pedagogical classes and districts of the region. The final stage is on the basis of TSPU. The Educational Academy "Success" has also been created at TSPU, on the basis of which regional Olympiads are regularly held, including in pedagogy.

\section{CONCLUSION}

The task of boosting the quality of training of pedagogical personnel shod be in the hands of the joint efforts of all persons and structures at the regional and federal levels involved in providing continuous pedagogical education, an important milestone of which is pre-professional pedagogical training of high-school students, which is one of the target functions of general education and professional organizations. At the same time, it is important not only to form students ' readiness for professional self-determination of socio-pedagogical professions, but also value-semantic guidelines, social competence. Graduates of psychological and pedagogical classes are active young people who show leadership qualities in transforming and improving the world around them, who are capable of self-improvement, self-education and self-improvement.

The activity of psychological and pedagogical classes should be aimed at the social and educational environment, introducing new elements and connections into it, taking into account the prospects for development and the request of the subjects of educational relations. To do this, it is advisable for students of psychological and pedagogical classes to join the design and implementation of social and educational programs of the organization, region, state, aimed at implementing the national project "Education" to search for project and implementation students of promising socially significant projects justified by them at the federal and regional levels.

Thus, the psychological and pedagogical class should become an environment (based on) the birth and implementation of future social and socio-pedagogical initiatives that lead time, renew the needs of the future generation of students and their parents.

Authors' Contributions: Chernyavskaya, A. P.: conception and design, acquisition of data, analysis and interpretation of data; analysis and interpretation of data, critical review of important intellectual content. Bayborodova, L. V.: conception and design, acquisition of data, analysis and interpretation of data; analysis and interpretation of data, critical review of important intellectual content. All authors have read and approved the final version of the manuscript.

Ethics Approval: Not applicable.

Acknowledgments: The article was written within the framework of the State Task of the Ministry of Education of the Russian Federation No. 073-00077-21-02 for the implementation of scientific research on the topic "Pre-professional pedagogical training of students in the system of continuous pedagogical education" (registry entry No. 730000F. 99.1. BV09AA00006).

\section{REFERENCES}

Aksu, M., Demir, C. E., Daloglu, A., Yildirim, S., \& Kiraz, E. (2010). Who are the future teachers in Turkey? Characteristics of entering student teachers. International Journal of Educational Development, 30(1), 91-101. https://doi.org/10.1016/i.ijedudev.2009.06.005

Brok, P. D., Wubbels, T., \& Tartwijk, J. V. (2017). Exploring beginning teachers' attrition in the Netherlands. Teachers and Teaching, 23(8), 881-895. http://dx.doi.org/10.1080/13540602.2017.1360859 
Brown, D. (Ed.). (2002). Career choice and development (4th ed.). San Francisco: Jossey-Bass Publ.

Chernyavskaya, A. P. (2017). Psychological prerequisites for the development of professional maturity of high school students. Yaroslavl Pedagogical Bulletin, 3, 166-169.

Chernyavskaya, A. P., Bayborodova, L. V., Golovinina, I. V., Gruzdev, M. V., Paputkova, G. A., \& Khodyrev, A. M. (2021). Pre-professional pedagogical training of schoolchildren in modern conditions. Proceedings of the Volgograd State Pedagogical University, 6(159), 4-10.

Choi, P. L., \& Tang, S. Y. F. (2009). Teacher commitment trends: cases of Hong Kong teachers from 1997 to 2007. Teaching and Teacher Education, 25(5), 767-777. http://dx.doi.org/10.1016/i.tate.2009.01.005

Danilova, L. N. (2018). Singapore's Educational leadership as a socio-cultural phenomenon. Yaros/avl Pedagogical Bulletin, 3, 55-62. https://doi.org/10.24411/1813-145X-2018-10067

Davydova, O. (2018). Interesting facts about the profession of "Teacher". Available:

https://rosuchebnik.ru/material/interesnie-fakti-o-professii-uchitel/ (date of access: 18.09.2021).

European Commission/EACEA/Eurydice. (2015). The teaching profession in Europe: Practices, perceptions, and policies. Eurydice Report. Luxembourg: Publications Office of the European Union, 138 p.

Flores, M. A., \& Day, C. (2012). Contexts which shape and reshape new teachers' identities: A multi-perspective study. Teaching and Teacher Education, 22, 219-132. https://doi.org/10.1016/j.tate.2005.09.002

Goodson, I. (2003). Professional knowledge, professional lives: Studies in education and change. Maidenhead and Buckingham: Open University Press.

Hattie, J. (2003). Teachers make a difference: What is the research evidence? In: Building teacher quality: What does the research tell us? ACER Research Conference,

Melbourne, Australia. Available: http://www.educationalleaders.govt.nz/Pedagogy-and-assessment/Buildingeffective-learning-environments/Teachers-Make-a-Difference-What-is-the-Research-Evidence (date of access: 18.09.2021).

Heinz, M. (2015). Why choose teaching? An international review of empirical studies exploring student teachers' career motivations and levels of commitment to teaching. Educational Research and Evaluation, 21(3), $258-297$. https://doi.org/10.1080/13803611.2015.1018278

Kyriacou, C., \& Coulthard, M. (2000). Undergraduates' views of teaching as a career choice. Journal of Education for Teaching, 26(2), 117-126. http://dx.doi.org/10.1080/02607470050127036

Lyng, S. T., \& Blichfeldt, J. F. (2003). Attracting, developing and retaining effective teachers. Country Background Report for Norway. OECD. Work Research Institute, 83 p. Available:

https://www.oecd.org/education/school/2635707.pdf

Manning, M., \& Patterson, J. (2005). Unfulfilled promise: Ensuring quality teachers for our nation's schools. Childhood Education, 81(4), 249-250.

Ministry of Education of the Russian Federation. (2018). National project "Education". Available:

https://strategy24.ru/rf/education/projects/natsionalnyy-proekt-obrazovanie (date of access: 18.09.2021).

Richardson, P. W., \& Watt, H. M. G. (2006). Who chooses teaching and why? Profiling characteristics and motivations across three Australian universities. Asia Pacific Journal of Teacher Education, 34, 27-56.

https://doi.org/10.1080/13598660500480290

Rikard, G. L. (1999). Promoting teacher commitment in pre-service teachers. Journal of Physical Education, Recreation \& Dance, 70(9), 53-56.

Smak, M., \& Walczak, D. (2017). The prestige of the teaching profession in the perception of teachers and former teachers. Edukacja. An interdisciplinary approach, 2017, 22-40. https://doi.org/10.24131/3724.170502

Stronge, J. H., Ward, T. J. \& Grant, L. W. (2011). What makes good teachers good? A cross-case analysis of the connection between teacher effectiveness and student achievement. Journal of Teacher Education, 62(4), 339-355. http://dx.doi.org/10.1177/0022487111404241

Stronge, J. H., Ward, T. J., Tucker, P. D., \& Hindman, J. L. (2008). What is the relationship between teacher quality and student achievement? An exploratory study. Journal of Personnel Evaluation in Education, 20(3-4), 165-184.

https://doi.org/10.1177/0022487111404241 
Struven, K., Jacobs, K., \& Daughters, F. (2013). Why do they want to teach? There are multiple reasons why different groups of students receive pedagogical education. European Journal of Educational Psychology, 28(3), $1007-1022$.

https://doi.org/10.1007/s10212-012-0151-4

UNESCO Institute of Statistics. (2013). A teacher for every child: Projecting global teacher needs from 2015 to 2030. UIS Fact Sheet, No. 27, October 2013. Available: http://uis.unesco.org/sites/default/files/documents/fs27-a-teacherfor-every-child-projecting-global-teacher-needs-from-2015-to-2030-en.pdf (date of access: 18.09.2021).

Watt, H. M. G., Richardson, P. W., Klusmann, U., Kunter, M., Beyer, B., Trautwein, U., \& Baumert, J. (2012). Motivations for choosing a teacher as a career: an international comparison using the FIT selection scale. Pedagogical and pedagogical education, 28(6), 791-805. https://doi.org/10.1016/j.tate.2012.03.003

Yüce, K., Shakhin, E. Y., Kocher, V., \& Kana, F. (2013). Motivations for choosing a teacher as a career: A look at teachers before starting work in the Turkish context. Asia-Pacific Education Review, 14(3), 295-306.

https://doi.org/10.1007/s12564-013-9258-9

Received: 12 August 2021 | Accepted: 4 November 2021 | Published: 21 December 2021

This is an Open Access article distributed under the terms of the Creative Commons Attribution License, which permits unrestricted use, distribution, and reproduction in any medium, provided the original work is properly cited. 